\title{
UNITED STATES CONTROLS ON FOREIGN DIRECT INVESTMENT: THE I969 PROGRAM
}

\author{
JoHN EuLICOTr*
}

Mandatory limits on foreign direct investment by U.S. persons and business entities were imposed on January $x, 1968$, by Executive Order 11387 , founded on section 5(b) of the $19 x_{7}$ Trading With the Enemy Act, as amended, ${ }^{1}$ and President Truman's I950 national emergency proclamation. ${ }^{2}$ The controls are embodied in the Commerce Department's Foreign Direct Investment Regulations, ${ }^{3}$ which have undergone numerous revisions since their original publication a year and a half ago. The Regulations supersede a "voluntary" private capital outlay restraint program administered by the Commerce Department from 1965 through 1967 in an effort to improve the U.S. balance-of-payments position. Although the voluntary program did reduce private capital outlays modestly, persistent deficits in the U.S. balance of payments and a loss of international confidence in the dollar following the devaluation of the British pound late in 1967 led the United States to conclude that more stringent measures were required, including the mandatory direct investment controls.

The goal of the mandatory controls for 1968 was a one billion dollar reduction in the foreign direct investment balance-of-payments category from the 1967 level of $\$ 3.7$ billion. The actual reduction has been reported as more than twice as much, ${ }^{4}$ but this accomplishment was more than offset by the virtual elimination of the nation's traditional trade balance surplus. Although an over-all balance-of-payments surplus was achieved for 1968 , this was regarded as due to transitory factors and not a fundamental improvement. ${ }^{5}$

Although the Nixon Administration is committed to removal of the mandatory controls on foreign investment, it recognizes that this removal must be made gradually and must be accompanied by improvement in the fundamental economic problems which created a persistent imbalance in the nation's balance of payments and provoked the dollar confidence crisis late in 1967 which led to the institution of the

\footnotetext{
- Partner, Covington and Burling, Washington, D.C.; Member, Advisory Committee on Regulations, Office of Foreign Direct Investment.

1 I2 U.S.C. \$95a (Supp. IV, I965).

2 Proclamation No. 2914, Dec. 16, I950, 50 U.S.C. $\$ \$ 9497$, I217I (I968).

I5 C.F.R. pt. I000, as amended, 34 Fed. Reg. 906 (1969). These regulations are cited hereinafter as OFDI Reg. $\$$, omitting from each section reference to the prefix "rooo" which it bears in the Code of Federal Regulations. For the most part the technical discussion omits specific section references but summarizes the Regulations as in effect on July 25, 1969.

'Testimony of Don D. Cadle, Acting Director, OFDI, Hearings on House Concurrent Resolutions 85 and 86 Before the Subcomm. on Foreign Economic Policy of the House Comm. on Foreign Affairs, 9Ist Cong., rst Sess. 218 (1969) [hereinafter cited as 1969 Hearings].

${ }^{\boldsymbol{B}}$ See Statement of Secretary of Commerce Maurice H. Stans, Hearings Before the Joint Economic Comm., 91st Cong., Ist Sess. 727 (1969), reporting a I968 trade surplus of \$9o million compared to $\$ 3.5$ billion in 1967 .
} 
controls. ${ }^{6}$ Since this fundamental improvement cannot be anticipated in the immediate future, the controls are being continued in effect at least for the remainder of 1969 and probably longer. ${ }^{7}$ However, significant liberalizations have been incorporated into the control framework since the end of 1968 .

\section{Summary of the Controls}

The Foreign Direct Investment Regulations (hereinafter the "Regulations") as in effect on July 25,1969 , including liberalizing amendments adopted by the Office of Foreign Direct Investments (hereinafter "OFDI") on June $18,1969,{ }^{8}$ and liberalized reporting requirements, ${ }^{9}$ both expected to be adopted shortly, contain the following major features:

(I) The controls apply to U.S. persons and business entities meeting the definition of a "direct investor," generally one who owns a ten per cent or greater equity position in a business venture outside the United States and its territories and possessions. Such a foreign business venture, in turn, is denominated an "affliated foreign national." Capital contributions, loans, and certain other capital transfers by direct investors to their affiliated foreign nationals together with the unremitted earnings of those affliated foreign nationals constitute "direct investment."

(2) The controls prohibit direct investment during any calendar year except as generally authorized by the Regulations or specifically authorized by OFDI upon individual application. The Regulations authorize unlimited investment in Canada. For the remainder of the world the direct investor may choose any of three general authorization limitations, informally described as "allowables":

(a) A worldwide minimum investment allowable of $\$ \mathrm{r}, 000,000$.

(b) A set of "earnings" allowables which are determined separately for each of three country groups, schedules A, B and C. The allowable for each schedule area is an amount equal to thirty per cent of the annual earnings of the direct investor's affiliated foreign nationals in that schedule area in the preceding year.

(c) A set of "historical" allowables which are determined separately for the

\footnotetext{
${ }^{6}$ See Statement by the President on the Balance of Payments, April 4, x969, accompanying Exccutive Order No. Ir464. N.Y. Times, Apr. 5, I969, at 39, col. 4 .

"The President's statement of April 4, I969, stipra note 6, looks to the rebuilding of the nation's traditional surplus in the trade account by restoring stable and noninflationary economic growth to the U.S. economy as the principal means for bringing about a fundamental improvement in the balance of payments. Recent studies have questioned whether the restoration of a trade surplus adequate to fill this need is a practical possibility even given favorable economic conditions. See, e.g., U.S. Dep'T or Comagerce, United States Foreign Trade (1969).

${ }^{8} 34$ Fed. Reg. $956_{4}$ (x969).

- See General Instruction B, Instructions for Completing the i969 Quarterly Report on Fors FDI-102 (rev. June 1969).
} 
three country groups and are based upon investment experience there in the 1964-1966 period.

Unused earnings and historical allowables in one schedule may be passed "downstream" (from C to B or A and from B to A) to other schedules. The historical allowables may also be passed "upstream" subject to a ceiling equal to the earnings allowable in the higher schedule. Finally, to the extent not utilized in the year at all, the historical and earnings allowables may be carried over to the next year. Some direct investors have historical allowable carryovers from I 968 which may be added to 1969 historical or earnings allowables. A supplemental worldwide "incremental earnings" allowable will become available in I970.

(3) Direct investment which is made with the proceeds of "long-term foreign borrowings" made by the direct investor or to which such borrowings are "allocated" by the direct investor is not counted in determining whether the investment allowables have been exceeded. However, repayments of such borrowings count as a form of direct investment subject to the controls. Moreover, in most cases the direct investor must repatriate to the United States by the end of each year all long-term foreign borrowing proceeds not physically invested at that time.

(4) The controls also prohibit direct investors from holding at each month-end "liquid foreign balances" which exceed the average month-end amount of the same outstanding in 1965-66. Liquid foreign balances include demand and short-term deposits in foreign banks and in foreign branches of U.S. banks, and certain other liquid foreign assets. Canadian balances are not counted. Unallocated proceeds of long term foreign borrowings are subject to year-end repatriation requirements.

(5) Most direct investors must file calendar quarterly and year-end reports demonstrating their compliance with the investment controls, but quarterly reports are not required, in most cases, if annual worldwide foreign investment (inclusive of Canada) beginning with $\mathrm{I} 968$, has not exceeded $\$ \mathrm{I}, 000,000$ (positive or negative) disregarding foreign borrowing offsets. Severe criminal penalties are prescribed for noncompliance, but OFDI has declared its intention to rely upon civil remedies embodied in informal "voluntary settlements," "consent agreements," and "orders" following a formal administrative proceeding. Such remedies may entail the loss of general or specific authorizations, disinvestment and/or the reduction of foreign balances.

\section{II}

\section{Direct Investors and Their Affiltated Foretgn Nationals}

The term "direct investor" is basic to an understanding of the investment controls since the controls apply to the foreign activities of these direct investors. The direct investor concept roughly but imperfectly complements the interest equalization tax ${ }^{10}$

\footnotetext{
${ }^{10}$ INT. REV. CODE of I954, $\$$ $\$ 9$ II-3I.
} 
a balance-of-payments measure dating from 1963 designed to discourage the acquisition of porffolio foreign securities by U.S. persons. That tax contains an exclusion ${ }^{11}$ for acquisitions of stock or debt obligations of a foreign corporation if immediately thereafter the acquiring U.S. person owns ten per cent or more of the combined voting power of all classes of the corporation's stock. In the case of a partnership the exclusion applies if the acquirer of the interest or obligation owns a ten per cent or more profits interest.

Under the controls a direct investor is a person within the United States owning or acquiring beneficially ten per cent or more of the total combined voting power of the outstanding securities of a foreign corporation, or a ten per cent or greater interest in the profits of a foreign partnership or other unincorporated foreign business venture. This direct investor concept is extended, however, when two more U.S. persons act in concert (but not through a U.S. corporation, partnership or trust) to own or acquire a foreign investment, such as in a joint venture. In these cases, if the combined holdings attain the ten per cent level, an "associated group" is deemed to exist, and each participant in the group is deemed to be a direct investor no matter how small his individual interest. In certain circumstances, however, the group members may report their investments as a group.

Although the requisite ten per cent interest in a foreign business may be held indirectly through others as well as directly, generally the direct investor will be the most immediate owner and others holding foreign business interests indirectly through a direct investor are disregarded. There are three exceptions to this rule. First, all corporations which are more than fifty per cent owned by a U.S. person are combined into an "affiliated group" which is treated as a single direct investor. Second, there is a "family group" concept combining as a single direct investor an individual person, his spouse and relatives sharing the same residence. Third, if there are ten or fewer persons holding direct interests in a direct investor, a majority in interest of these indirect owners may make an election to have the direct investor disregarded and divide its investment among themselves according to their interests in the direct investor.

The foreign corporation, partnership, or business venture in which a direct investor has the requisite interest to qualify as such is known as an "affiliated foreign national" of that investor. The term "business venture" is broadly interpreted. It includes, for example, an overseas sales or manufacturing branch of the direct investor. However, there must be a degree of permanency to justify recognition that a distinct business venture exists. An OFDI Bulletin states that the "permanent establishment" concept of U.S. tax treaties ${ }^{12}$ as well as the traditional "doing business" tests of state law may be "useful guidelines" in determining whether there is a busi-

\footnotetext{
${ }^{11}$ INT. REv. CoDE of 1954, $\$ 4915$.

${ }^{13}$ INT. Rev. CODE of I954, \$864(c).
} 
ness venture. ${ }^{13}$ Specifically included in the business venture category are foreign real estate primarily held for business or investment (whether or not developed), and contract construction, engineering, oil exploration and similar operations involving a job site or project office in a foreign country. Bank accounts, rented warehouses, and transitory service operations do not, in themselves, constitute affiliated foreign nationals.

The affiliated foreign national concept applies to second-tier affiliates, branches of affiliates, and other indirectly owned foreign business as well as to the first offshore affiliate, provided multiplication of the interests in the ownership chain establishes a direct investor-affilated foreign national relationship. For example, if an investor held a twenty per cent voting stock interest in a foreign corporation which in turn owned fifty per cent of the voting stock of a second foreign corporation, the latter corporation would be an affiliated foreign national of the investor since the investor's interest is ten per cent $(20 \% \times 50 \%)$.

Because the direct investment limitations differ according to the three groups of foreign countries, the country in which each affliated foreign national is located is significant. The less developed countries are grouped into schedule $A$; most of the old sterling area, the Middle East oil-producing countries, and Japan into schedule $\mathrm{B}$; and the remaining countries, primarily continental Western Europe, into schedule C. Canada is substantially excluded from the program.

III

\section{Direct INVESTMENT Limitations}

The Regulations prohibit direct investment during any year in the investor's affiliated foreign nationals except within the investor's general authorization limits, the "allowables," or as permitted on application by specific authorization or exemption. Except where permission is given to measure compliance on the basis of the investor's fiscal year, ${ }^{14}$ direct investment is computed on the basis of the calendar year in order to coincide with the nation's balance-of-payments reporting. However, the investor may elect to treat dividends from incorporated affiliated foreign nationals -a reduction of direct investment-which are received within sixty days after the end of each year as received during the preceding year. Also, the investor may allocate foreign borrowing proceeds to direct investment-reducing the latter-after year-end if the proceeds were available at year-end and the allocation is reported on the investor's annual report to OFDI due within r20 days after year-end.

Among the factors that have made it virtually impossible to administer the controls on investment by any period shorter than a year, despite the requirement that quarterly reports be filed, are the structure of the Regulations themselves, in-

\footnotetext{
${ }^{13}$ OFDI General Bulletin No. I, Interpretative Analyses and Statements $\$ B_{304}(d), 33$ Fed. Reg. 15167 ( 1968 ) [hereinafter cited as GEN. BuLL. No. I].

${ }^{14}$ It is understood that such permission has been given in only a handful of cases.
} 
cluding choices among investment allowables and the availability of foreign borrowing offsets; the unpredictability of the investor's year-end position, particularly the level of foreign affiliate earnings; and the complexity and unfamiliarity of and frequent changes in the Regulations to date. Explanations are called for on the quarterly report form if cumulative direct investment at the end of the first, second, or third quarter is in excess of forty, sixty-five or eighty-five per cent, respectively, of the investment allowables available to the direct investor for the year. However, it is probable that such information will serve as a reminder to the investor of the need to improve his position by year-end rather than as a basis for any compliance action (other than some informal communication) by OFDI, despite a provision in the Regulations permitting OFDI to shorten an investor's compliance period or reduce allowables where investment in any quarter is "materially in excess of twentyfive per cent of the amount thereof generally authorized to such direct investor during the year," particularly if it cannot be shown that "the transactions resulting in such excess during such quarter are in accordance with the customary business practices of the direct investor."15

\section{A. The Elements of Direct Investment}

The two components of direct investment are "transfers of capital" to the investor's affiliated foreign nationals and "reinvested earnings" of the investor's incorporated affiliated foreign nationals. Although, in their earlier phases, the Regulations distinguished between these two components in many significant respects, the two have now been substantially merged in measuring compliance with investment allowables. Thus, for most purposes, the significant figure is the net total of the investor's capital transfers and reinvested earnings either within a country group schedule or worldwide during a compliance period. And, in computing these net totals, the investor may deduct the available proceeds of long-term foreign borrowings expended in making transfers of capital or allocated to such transfers or to reinvested earnings.

\section{Transfers of Capital}

The term "transfers of capital," one of the two components of direct investment, refers to a change in the equity and debt position of a direct investor in the investor's affiliated foreign nationals. Certain changes in the affiliate's ownership interest in or holdings of debt of the direct investor are also regarded as transfers of capital, but these are relatively uncommon as, by definition, the direct investor must hold at least a ten per cent interest in each affiliate and in most cases will not be owned by or borrow funds from the affliate.

Capital may flow in either direction. As funds are contributed or loaned by a

${ }^{15}$ OFDI Reg. $\S 201$ (d) (I969). 
direct investor to its affliates there is an outward or "positive" transfer of capital. As the affiliate repays indebtedness or is liquidated there is a "negative" transfer. It is the net outward flow, or net positive transfer of capital, within a compliance period which the Regulations limit as one of the two components of direct investment.

Contributions to the capital of or loans to incorporated affliated foreign nationals by direct investors are the most common types of capital transfers. These need not be formal stock purchases or loans. It is sufficient if funds or property are transferred to the affiliate without an offsetting transfer of funds or property by the affilate. For example, the sale of merchandise on open account to an affiliate results in a transfer of capital. The leasing of property to an affliate also is regarded as a transfer of capital if the property has more than a one-year life and is not to be returned within that period.

Noncapital transactions with affliates (or with third parties on behalf of affliates) do not enter into the capital transfer computations. Such transactions include the payment of interest, the payment of rent, the payment of license royalties, the making of a guarantee, a reappraisal of assets, the reinvestment of corporate earnings, or the transfer of patents, copyrights, trademarks, trade names, trade secrets, technology, proprietary processes, proprietary information or similar intangibles or any rights or interests therein or applications or contracts relating thereto (except under unusual circumstances).

Acquisitions of interests in affiliated foreign nationals from third parties are considered to represent a transfer of capital unless the transferor of the interest is a direct investor. The transfer is deemed to be to the place where the affiliate is located, not to the place where the transferor of the interest is located. If the transferor is a direct investor there is no transfer of capital, but the transferee becoming a direct investor by virtue of the acquisition succeeds to the transferor's investment position with respect to the acquired interest. Where a direct investor comes to be such through gradual acquisition of the requisite ten per cent interest in an affiliate, a special rule picks up all capital transfers in the twelve months preceding the date on which the ten per cent ownership level was attained. Dispositions of interests in or obligations of an affliated foreign national are regarded as negative capital transfers only if the transferee of the interest is a foreign national or, in certain cases, a bank or other financial institution.

Other third-party transactions can result in a transfer of capital. If the direct investor discharges the obligation of an affiliated foreign national to a third party, pursuant to a guarantee or otherwise, a transfer of capital to that affliate is deemed to result. Likewise, if the investor makes a deposit with a foreign bank or otherwise transfers securities or obligations of a nonaffiliated foreign issuer to secure the transfer of funds or property by a foreign party to the investor's affiliate, there is deemed to be a transfer of capital to that affliate. And, if the direct investor repays a long-term foreign borrowing the proceeds of which were expended in making or allocated to 
an earlier direct investment in an affiliate, that repayment is deemed to be a transfer of capital to the place of the affiliate to which the borrowing proceeds are allocated at the time. A refinancing of such a borrowing by its renewal, extension, or continuance or by a replacement long-term foreign borrowing is not considered a repayment, but the delivery of equity securities pursuant to conversion rights granted to holders of the debt is regarded as a repayment.

Cross-schedule interaffiliate capital transfers enter into the investment calculations of the Regulations only if at least one of the affiliates is majority-owned by the direct investor. If that is the case the transfer is regarded as flowing from the transferor to the direct investor (a negative investment) and thence from the investor to the transferee (a positive investment). Interaffiliate capital transfers are also disregarded, even with majority-ownership of either or both by the direct investor, if the transfer results from an ordinary arms-length trade credit extended by one affiliate to the other paid within twelve months, provided neither affiliate is Canadian.

In the case of unincorporated affiliates, net capital transfers during any period to (or from) an unincorporated affiliated foreign national are measured by the increase (or decrease) in the direct investor's share of the net assets (disregarding any debt or ownership relationship with the direct investor) of the affiliate. If an unincorporated affiliate generates income and this is not remitted to the investor, net assets increase and a transfer of capital is deemed to have occurred to the extent of the investor's share of those earnings. On the other hand, these earnings do not enter into the reinvested earnings component of direct investment (see below). Similarly, if funds are loaned or contributed to the unincorporated affiliate by the direct investor, net assets increase since the equity or debt change is ignored and a transfer of capital is deemed to have occurred. However, in the case of unincorporated affliates, such as partnerships and joint ventures, which are not wholly-owned by the direct investor, transfers by co-owners do not enter into these computations and the direct investor's transfers are fully included despite the investor's less than roo per cent interest in the affliate's net assets.

\section{Reinvested Affliate Earnings}

The other component of direct investment is the direct investor's share of the reinvested earnings of the investor's incorporated affiliated foreign nationals. This involves, first, a computation of the investor's share of incorporated affiliate earnings and, second, the reduction of this amount by dividends paid out to determine what is left as reinvestment.

Earnings (or losses) of incorporated affiliates are to be computed in accordance with accounting principles generally accepted in the United States and consistently applied. U.S. taxes and foreign dividend withholding taxes are ignored. For the purpose of determining compliance with schedule area allowables the investor's share 
of earnings (and losses) of all incorporated affiliates in that schedule are combined, excluding from the computation (i) dividends to those affiliates from other incorporated foreign affliates of the investor and (ii) earnings of those affiliates from unincorporated affiliates of the investor in different schedule areas.

To compute reinvested earnings, this combined earnings (or loss) figure is then (I) reduced by the sum of the dividends paid to the direct investor by such affiliates and the direct investor's share of the dividends paid by such affiliates to the investor's affiliates in other schedule areas, and (2) increased by the sum of the investor's share of dividends paid to the affiliates in the schedule area in question by the investor's incorporated affliates in other schedule areas and the investor's share of all earnings deemed to be remitted to the affiliates in the schedule area in question by unincorporated affiliates in other schedule areas. Earnings of unincorporated affiliates are deemed to be remitted to the extent they exceed the affiliate's growth in net assets.

Dividends are calculated before deducting foreign withholding taxes. They are considered "paid" when entered on the books of the recipient as paid in cash or subject to payment on demand. There is a provision for electing to treat dividends paid within sixty days after the end of the year as having been paid during such year if this treatment is followed consistently in reporting to OFDI.

\section{B. Investment Allowables}

Each direct investor may elect any one of three investment allowables for use in I 69 , a worldwide $\$ \mathrm{I}, 000,000$ "minimum" allowable, a set of country group "earnings" allowables based on earnings of the investor's affiliates in those country group schedules in the preceding year, or a set of country group "historical" allowables based on investment in those country group schedules in the $1964-66$ period. Although a tentative choice of allowables is to be indicated on the investor's quarterly reporting forms, a binding election is not required until the annual report due within 120 days after year-end. An additional "incremental earnings" supplemental allowable will become available in 1970. Investment in Canada is authorized without restriction as to amount.

The worldwide $\$ 1,000,000$ minimum allowable is substantially more generous than the comparable Ig68 minimum investment authorization, which was set initially at $\$ 100,000$ and later increased to $\$ 200,000$. With a single exception, worldwide annual direct investment (exclusive of Canada) is netted to determine whether the limitation has been exceeded. The exception is that if the investor's affiliated foreign nationals (both incorporated and unincorporated) have an aggregate annual loss, this loss may not be subtracted in computing whether worldwide investment exceeds the $\$ 1,000,000$ limitation.

Since investment is determined after netting out any proceeds of long-term foreign borrowings expended in or allocated to such investment, it is possible for firms with 
substantial foreign operations as well as medium and small firms to make use of the minimum allowable. However, if net investment exceeds the $\$ 1,000,000$ minimum allowable ceiling, the allowable is lost altogether. And, if the minimum allowable is used but net worldwide investment falls short of $\$ \mathrm{r}, 000,000$ there is no carryover of unused allowables to later years. ${ }^{18}$ Also, any Ig68 historical investment allowable carryovers will be lost if the minimum allowable is used in 1969 .

The earnings allowable in each schedule area is an amount equal to thirty per cent of the direct investor's share of the aggregate net earnings of its affiliated foreign nationals, both incorporated and unincorporated, in that schedule area in the preceding year. The election to utilize the earnings allowables must be made for all three schedule areas if made for any one. However, it is binding only for the year for which it is made.

The historical investment allowables likewise are separate investment allowances for each of the three schedule areas which may be elected annually for the three schedules together. In schedule $A$ the allowable is an amount equal to iro per cent of the direct investor's average $1965-66$ annual direct investment in schedule A. In schedule $B$ the allowable is an amount equal to sixty-five per cent of the direct investor's average $1965-66$ annual direct investment in schedule B. In schedule C the allowable is the lesser of (I) an amount equal to thirty-five per cent of the direct investor's average $1965-66$ annual direct investment in schedule $C$ or (2) an amount computed by applying to the direct investor's share of the current year's earnings of its schedule $\mathrm{C}$ incorporated affiliated foreign nationals a percentage which is equal to the average percentage of its share of schedule $C$ incorporated affiliate earnings which were reinvested in $1964-66$, inclusive. ${ }^{17}$

The earnings or historical allowables may be utilized to cover any combination of capital transfers and reinvested earnings. Unused allowables may be passed downstream from schedule $C$ to schedule $B$ or $A$ and from schedule $B$ to $A$. Unused historical allowables may be passed upstream subject to an over-all limitation in the upper schedule equal to what the earnings allowable for the upper schedule would have been had it been elected. To the extent not so exhausted by the downstream or upstream shifts, unused earnings or historical allowables for 1969 or later years may be carried forward to the succeeding year within the same schedule area to supplement earnings or historical allowables in those years. Also, unused 1968 historical allowables may be used to supplement 1969 earnings allowables in the same schedule area.

The "incremental earnings allowable" is a supplemental general investment

\footnotetext{
${ }^{18}$ Investors which utilized the minimum $\$ 200,000$ allowable in $x 968$ are permitted to carry forward unused historical allowables to 1969 reduced to the extent of 1968 investment covered by the minimum allowable.

${ }^{17} \mathrm{An}$ additional aspect of the historical allowable in schedule $\mathrm{C}$ is that if this schedule's incorporated affiliated foreign nationals have an aggregate net loss, this "hole" may not be filled by a transfer of capital. However, this aggregate loss may be carried forward to authorize reinvested schedule $\mathbf{C}$ incorporated affliate earnings in later years.
} 
authorization which will not become available to investors until r970. However, it has significance in 1969 for planning purposes, particularly in connection with the possible future repayment of long-term foreign borrowings used presently to offset direct investment (see below). The incremental earnings allowable is a worldwide investment authorization in an amount equal to the excess of ( $I$ ) forty per cent of the difference between the investor's share of the total earnings of its affiliated foreign nationals (exclusive of Canada) in the current year and the average (but not less than zero) annual earnings of such affiliates in $1966-67$, over (2) the investor's minimum allowable, earnings allowables, or historical allowables for the current year, whichever is highest.

Special investment authorization rules have been prescribed for air carriers and contractors. Proposed special rules for the mining and petroleum industries were recently withdrawn.

In addition to these general investment authorizations, the Regulations make provision for the issuance of specific investment authorizations or exemptions on individual application to OFDI. Numerous specific authorizations were issued in 1968,18 many to accommodate commitments predating the imposition of the mandatory controls, others to take care of hardships created by the particular circumstances of the investor, and still others to overcome shortcomings in the structure of the Regulations which had not evolved to their present state. Applications for specific investment authorizations have declined sharply with the liberalization of the Regulations in 1969 and clarification of OFDI's specific authorization policies. In the absence of significant new developments (such as the continued unavailability of foreign financing which has become scarce and expensive in the first half of I969), it would appear that OFDI expects specific authorization requests in Ig6g to consist primarily of applications to permit open account growth accompanying increased exports to foreign affiliates and applications to authorize foreign acquisitions for the investor's equity securities. Other applicants will be forced to pass stringent foreign borrowing unavailability standards. ${ }^{19}$

Recently, OFDI announced that it had developed a specific authorization policy with regard to the treatment of foreign investment financed with equity securities. ${ }^{20}$ Under the Regulations the acquisition of an interest in an affiliated foreign national for equity securities of the investor is a transfer of capital. The investor's securities given in exchange for the interest represent a potential claim on U.S. funds because of their possible sale to U.S. persons. However, such sales may not occur and, to the extent they do not, equity financing of foreign investment may be preferable to debt financing since the latter must eventually be repaid and such repayment will

\footnotetext{
${ }^{18}$ See Statement of Don D. Cadle, Acting Director, OFDI, 1969 Hearings, supra note 4 , at 218 , that in 1968 OFDI processed 1259 applications for specific authorizations, of which only 98 were denied completely.

${ }^{10}$ See Memorandum for Direct Investors, from Richard P. Urfer, Director, OFDI, June 6, r969.

${ }^{30}$ OFDI News Release FDI 69-9, July r4, 1969.
} 
constitute a balance of payments outflow. The equity financing specific authorization policy provides for the issuance of qualified investment authorizations on individual application in three situations: (I) Authorizations may be issued to treat convertible preferred stock of the investor's domestic international finance subsidiary in the same manner as convertible debt instruments so that proceeds derived from the issuance of these convertible preferred shares to foreign nationals will qualify as foreign borrowings available to offset investment. (2) Authorizations may be issued to defer the transfer of capital charge where foreign investment is accomplished by the issuance of the direct investor's equity securities to a "limited group" of foreign nationals and there is "adequate assurance that such shares will not be sold or otherwise disposed of within three years." If and when such dispositions do occur, transfers of capital will be charged but apparently these will be limited to the value of the equity securities when issued. (3) Authorizations may be issued in other "appropriate situations" to spread eighty per cent of the capital transfer charge resulting from foreign investment accomplished with equity securities over a six-year period and relieve the investor of the remaining twenty per cent.

\section{IV}

\section{Foreign Borrowing Offsets}

The Regulations provide that in computing the direct investor's net transfers of capital to affiliated foreign nationals there shall be deducted an amount equal to the proceeds of "long-term foreign borrowings" made in the same or prior years and expended in making, or allocated to offset, such transfers on the books and records of the direct investor and on the investor's annual OFDI report. In addition, beginning in 1969 , an investor may allocate the proceeds of long-term foreign borrowings to its share of the reinvested earnings of its affiliated foreign nationals, thereby reducing these reinvested earnings by the amount so allocated. Thus, it is possible to undertake or continue a foreign investment program in any amount and in any form so long as the investor can continue to finance or match this investment with an equal amount of long-term foreign borrowings.

Moreover, beginning in 1969 and in succeeding years the investor is free to reallocate foreign borrowing proceeds first expended or allocated during ${ }^{9} 68$ or any succeeding year between schedule areas from time to time to assist in complying with the investment limitations of the controls. For example, if borrowing proceeds were initially expended in making or were allocated to a capital transfer to a schedule $\mathrm{A}$ affiliated foreign national during 1968 and in 1969 the investor has excess investment in schedule $\mathrm{C}$ but unused investment authorizations in schedule $\mathrm{A}$, the borrowing, if still outstanding, could be reallocated to schedule $C$ investment in 1969 , but at the price of an equivalent transfer of capital charge to schedule $A$ in 1969 . However, there is no longer any mechanism in the Regulations for simply "de-allocating" borrowing 
proceeds and restoring their status as such at the price of charging a transfer of capital to the place where the proceeds are allocated at the time. Nor are borrowing proceeds which have been expended in making capital transfers deemed to be restored when such transfers are reversed; the reversal is simply a negative capital transfer, and the borrowing proceeds are deemed to remain invested. ${ }^{21}$

A condition of the right to allocate proceeds of long-term foreign borrowings to offset direct investment is the requirement that, as of the end of the year for which the allocation is made, the proceeds so allocated (except for proceeds representing discounts, commissions, or fees) be held in the United States and not held in the form of foreign balances, securities, or other property. Thereafter, so long as the allocated borrowings are outstanding, the proceeds must remain so held except that they may be expended in making capital transfers within the limits of investment allowables. The requirement that allocated borrowing proceeds be repatriated may create a tax hardship for domestic finance subsidiaries subject to the withholding tax requirement that eighty per cent of interest income be foreign-source (see below), and OFDI has expressed a willingness to consider specific authorizations in such instances. ${ }^{22}$

To qualify as a long-term foreign borrowing the lender must be an unaffiliated foreign (and non-Canadian) person, including a foreign branch or office of a U.S. bank. The maturity must be at least twelve months. If the lender is other than a bank or foreign government, the loan must have at least a three-year maturity and be subject to the interest equalization tax if sold to a U.S. national or resident, or the lender must agree in writing not to transfer the loan obligation to a U.S. or Canadian national or resident, or to any person he has reason to believe will sell to either, for at least three years. The definition of long-term foreign borrowings is sufficiently broad to include contractual obligations to pay money arising out of an acquisition of an interest in a foreign business-for example, promissory notes, installment payment obligations, or debentures issued to the shareholders of a foreign corporation in exchange for their stock.

The "proceeds" of such borrowings which may be expended in making or allocated to offset direct investment are the gross value of the debt instruments before subtracting any discounts, commissions, or fees, and so may exceed the actual monies or property received. On the other hand, repayments of borrowings the proceeds of which were expended in making or allocated to offset direct investment count as capital transfers in the amount of the indebtedness thereby discharged. This

\footnotetext{
21 The Regulations in effect for 1968 provided that the repayment or other liquidation of direct investment in an affiliated foreign national which was created with foreign borrowing proceeds would be treated as a restoration of those proceeds rather than a negative capital transfer. OFDI Reg. $\$ 324$ (c) (I969).

${ }^{22}$ See 34 Fed. Reg. I2173-74 (I969). In I968 there was no requirement that allocated borrowing proceeds be repatriated to the United States other than the month-end limitation on all liquid foreign balances. See infra. Thus, domestic finance subsidiaries could park these allocated proceeds in Canada or in nonliquid foreign balances to avoid defeating the $80 \%$ foreign-source interest income requirement.
} 
rule is followed in the case of convertible debentures regardless of the value of the stock issued on conversion. The repayment charge is to the schedule area where the borrowing proceeds are invested or to which they are allocated at the time of repayment.

Because the future repayment of a long-term foreign borrowing expended in making or allocated to direct investment will constitute a transfer of capital which may be subject to the investment controls, both the borrowing investor and the lending foreign national will be concerned as to whether such repayment will be permitted. A similar problem exists with respect to guarantees of affiliate borrowings by investors (or by other affliates in different schedule areas) the satisfaction of which would constitute capital transfers. The foreign lender is assured the ability to collect in these situations by a provision in the Regulations which states that, so long as the lender does not have "actual knowledge" at the time of making the loan that its repayment (or other transaction in connection with the borrowing) will violate the Regulations, the lender may enforce its obligation and will not be subject to penalty for violating the Regulations. For the investor, subpart $J$ of the Regulations contains an authorization to repay long-term borrowings used for investment and to fulfill guarantees of affiliates provided the investor has complied with a certification requirement.

The investor's subpart J certificate must be filed with the Department of Commerce on form FDI-I06 within ten days after the date of the borrowing or making of the guarantee and must identify the lender, state the amount of the borrowing, and set forth the required principal repayments. In addition the investor must certify the investor's belief, giving the reasons therefor, that on the basis of the facts and circumstances existing at the time of delivery of the certificate, either (i) there will be no transfers of capital in connection with any repayments of the borrowings within seven years or (ii) any such transfers will not result in investment in excess of the investor's authorization limits in this initial seven-year period. Conversion rights may be ignored in making these repayment representations if the debt instrument has at least a seven-year maturity and if the instruments were sold in a public offering or are nonconvertible for three years.

Although subpart $J$ authorizes loan repayments where a proper certificate has been filed, the investor suffers a reduction in investment authorizations if and when such repayment occurs, even if this is after the seven-year certificate repayment representation period. The reductions normally take place in the same year as the repayment, and, if that year's reductions do not offset the repayments, the authorizations for succeeding years are reduced until there is a matching offset. In the case of repayments by the exercise of conversion rights the reductions are made in the year following conversion.

Most large foreign debt financings have involved the public sale of debentures of finance company subsidiaries in the European market. To ensure that the interest 
on such securities will not be subject to U.S. withholding taxes, most investors have utilized either of two vehicles. One is the U.S. incorporated finance subsidiary set up so as to qualify for exemption from U.S. withholding tax, one condition of which is that no more than twenty per cent of the subsidiary's interest income may come from U.S. sources. The other is an "off-shore" finance subsidiary, generally incorporated in the Netherlands Antilles to take advantage of favorable tax provisions there. The principal advantage of the off-shore companies is that they may loan funds to the parent corporation for use in the United States or invest in the United States in other ways free of the twenty per cent U.S. source interest income limitation of U.S. incorporated concerns. However, since the foreign borrowings of the off-shore companies do not constitute long-term foreign borrowings of the direct investor under the Regulations, it is necessary for the investor to obtain a specific authorization to have them so treated in order to make effective use of the off-shore finance company for purposes of the investment controls. Numerous such specific authorizations have been issued, and OFDI is studying amendments to the Regulations which would permit the off-shore finance subsidiaries to operate effectively under the control program without specific authorization.

\section{V}

\section{Foreign Balance Limitations}

There are two distinct limitations on the holdings by direct investors of "foreign balances." Foreign balances consist of (I) deposits (including certificates of deposit and fixed interest deposits) in foreign banks (including foreign branches of U.S. banks); (2) negotiable instruments, nonnegotiable instruments acquired after June $3^{\circ}$, I968, and commercial paper of an unaffiliated foreign national, other than certain export papers; and (3) securities issued or guaranteed by a foreign country.

One limitation prohibits a direct investor not electing to use the $\$ \mathrm{I}, 000,000 \mathrm{mini}$ mum investment allowable from making any net positive transfer of capital to any schedule area during that year to the extent the same results in positive direct investment in that schedule (i.e., is not offset by foreign borrowing proceeds, affiliate losses, or dividends in excess of earnings), regardless of whether this investment would otherwise be within the investor's historical or earnings investment allowables, if, at year-end, the investor holds unexpended and unallocated long-term foreign borrowing proceeds in the form of foreign balances exceeding a $\$ 25,000$ floor. The effect of this prohibition will, in most cases, be to force investors to choose between (I) repatriating unexpended and unallocated borrowing proceeds at year-end or (2) forgoing the use of historical or earnings allowables and offsetting investment exceeding the minimum allowable with the expenditure or allocation of borrowing proceeds. While proceeds allocated to investment also will have to be repatriated, these sums may be less than the unallocated and unexpended borrowing proceeds 
which would be forced back if historical or earnings allowables were utilized. OFDI has indicated a willingness to consider specific authorizations where the limitation on foreign balances representing borrowing proceeds would produce a tax or other hardship for the investor.

The second limitation applies to the holding by the direct investor of foreign balances which are in liquid form and do not represent the unallocated proceeds of long-term foreign borrowings. Subject to a $\$ 25,000$ floor, the Regulations require direct investors to limit the amount of liquid foreign balances outstanding at the end of any month to the average end-of-month amounts of the same outstanding during $1965-66$. This average is computed by totaling the twenty-four end-of-month balances for $1965-66$ and dividing this sum by twenty-four. Zero-balance months count as part of (and so reduce) the average.

The "liquid foreign balances" subject to this month-end limitation consist of foreign balances other than ( $\mathrm{I}$ ) foreign balances representing the proceeds of longterm foreign borrowings not allocated to direct investment; ${ }^{23}$ (2) Canadian balances; (3) certain nonredeemable, nontransferable, and nonmarketable foreign securities acquired by the direct investor before June 30, I968; (4) bank deposits and foreign debt securities, with a period of more than one year remaining to maturity when acquired by the direct investor and not redeemable by the direct investor within such period; (5) foreign balances subject to restrictions of a foreign country on liquidation and transfer; and (6) foreign balances which have been pledged or hypothecated in connection with borrowings by the direct investor or its affiliated foreign nationals. Liquid foreign balances are deemed to be held by the direct investor if $(\mathrm{I})$ held by another "principally formed or availed of" for such purpose; or (2) held by another (such as a foreign affiliate of the direct investor), and returnable to the direct investor on demand without material conditions, and not related to the business needs of the holder. OFDI has stated that the mere existence of a stock control relationship over the holder by the direct investor will not invoke these rules. $^{24}$

\section{Conclusion}

Although the mandatory investment controls have been strongly criticized in some business quarters as inequitable, discriminatory, and contrary to the long-run economic interests of the United States, ${ }^{25}$ there has been no public indication to date that compliance with the controls has been unsatisfactory. To the author's knowledge the Regulations have not been challenged in court. Hearings have been held on resolutions introduced in the House of Representatives calling for an end to the controls

\footnotetext{
${ }^{23}$ Foreign borrowing proceeds which have been allocated to investment would be subject to limitation as liquid foreign balances. However, since such allocations do not become final until after year-end and since year-end repatriation of such allocated proceeds is required by other provisions of the Regulations, the liquid foreign balance limitations would appear to be superfuous in this context unless the investor has received a specific authorization relieving it from the year-end repatriation requirement.

${ }^{24}$ GrN. Bull. No. I, \$B203, 33 Fed. Reg. 15164 (1968).

${ }^{25}$ See 1969 Hearings, supra note 4 .
} 
"at the earliest possible date,"26 but the resolutions have not been reported out of Committee.

Several reasons can be given for what may be characterized as the reluctant tolerance of the controls by the business community to date. First, those responsible for the structure of the Regulations and their administration have been generally sensitive to practical business problems, and this awareness has been reflected in an almost continuous evolution of the Regulations and authorization policies within the limits of the over-all balance-of-payments goals of the program. Second, the foreign borrowing offset feature of the controls and the availability of foreign financing in Ig68 made it possible for almost all businesses to continue their planned foreign investment through I 968 despite the limitations of the control system. Third, businesses with substantial foreign activity appreciate the importance of maintaining the strength of the dollar as an international currency and recognize that the controls did help to avert a serious dollar crisis at the outset of 1968.

Nevertheless, the controls do have serious shortcomings. Their dependence upon foreign borrowing makes them tolerable only so long as foreign credit remains available to all at reasonable cost. Recent developments in the European capital markets have created substantial doubt as to such continued availability of foreign funds. Moreover, even if foreign financing can be obtained, increasing borrowings to finance investment may create a "debt overhang" which will force a prolonging of the controls. The Regulations also suffer from their complexity and their frequent revision, which have made the control system generally more equitable and less burdensome but have also impeded broader understanding on the part of those affected. Finally, there is a fundamental question as to whether it is necessary or wise, from a balance-of-payments standpoint, to equate retained foreign earnings with outflows of U.S. capital and to control both.

While one study has suggested that a real cutback in U.S. direct foreign investment may not be undesirable, at least from a balance-of-payments standpoint, ${ }^{27}$ the basis for this thinking has been questioned, ${ }^{28}$ and it does not appear to be accepted by the current Administration. The direction, thus, appears to be clear-elimination of the controls. The fact remains that this cannot be accomplished without some immediate cost to the nation's balance of payments at a time when our payments position is not at the desired level and may not be restored to such a level for a considerable period. Despite this fundamental problem it may be advisable to assume the balance-of-payments risk of dismantling the controls rather rapidly before they become too ingrained and before foreign debt has built up to an unhealthy level.

\footnotetext{
${ }^{20} \mathrm{Id}$.

${ }^{27}$ G. Hufbauter \& F. Adler, Overseas Manufacturing Investment and the Balance of Payments (Treasury Department Tax Policy Research Study No. I, I968).

${ }^{28}$ See, e.g., R. Vernon, U.S. Controls on Foreign Direct Investments-A Re-evaluation (Financial Executive Research Foundation, Inc., I969); Machinery and Allied Products Institure Council for Technologicaz Advancement, The Case Aganst Balance-of-Payments Controls (ig68).
} 